\title{
Effect of Soil Types on the Development of Water Levels and Erosion Processes during Overtopping Test
}

\author{
Marwan Adil Hassan a ${ }^{\mathrm{a}}$, Mohd Ashraf Mohamad Ismail ${ }^{\mathrm{b} *}$ \\ ${ }^{a}$ Ph.D. student, School of Civil engineering, Universiti Sains Malaysia, Engineering Campus, 14300 Nibong Tebal, Pulau Peneng, Malaysia. \\ ${ }^{b}$ Senior Lecture, School of Civil engineering, Universiti Sains Malaysia, Engineering Campus, 14300 Nibong Tebal, Pulau Peneng, Malaysia.
}

Received 28 August 2018; Accepted 11 October 2018

\begin{abstract}
The construction of dike materials is an essential parameters in controlling the safety of hydraulic engineering. The dike material is an earthfill material constructed from non-cohesive materials or mixed from cohesive and non-cohesive materials. Overtopping failure can affect the dike stability during water cross above dike crest and could threat people lives and property. It is reduced the matric suctions binds soil particles due to the increasing volumetric water content during the transition of water level from the upstream into downstream slopes. In this paper, two spatial overtopping tests are conducted in Hydraulic Geotechnical laboratories at the Universiti Sains of Malaysia to observe the evolution of horizontal and vertical water levels as well as the development of lateral and vertical erosion processes under constant inflow discharge of $30 \mathrm{~L} / \mathrm{min}$. The vertical and horizontal water levels as well as the vertical erosion process are measured using one digital camera installed in front of dike embankment, while the horizontal erosion process was measured using another digital camera installed in front of downstream slope. Two types of coarse sand and very silty sand soils are used to construct dike embankment in small flume channel. The small flume is constructed from transparent PVC material to observe the development of water distributions and erosion processes with sediment box to collect the eroded materials. A pilot channel is cut in dike crest along the side wall of small flume channel to initiate breach channel in the dike crest. The initiation of breach channel is crucial for the evolution breach channel failure in the downstream and upstream slopes. The results show that the vertical and horizontal water levels are distributed faster in coarse sand soil compared with those in the very silty sand soil while the horizontal water levels are distributed faster than vertical water levels for both soils. The permeability of coarse sand increases the velocity of water flow for occupation soil particles and beginning failure in dike crest faster. The presence of fine particles in the very silty sand has reduced the rate of erosion processes inside dike particles in horizontal and vertical directions. The fine particles absorb a large amount of water content and, thus reduce the easiest water infiltration into particles with higher matric suctions. The analyzing of the distributions of water levels and erosion process help to understand the behavior of dike embankment during overtopping failure and increase the maintenance for dikes parts to reduce the potential danger.
\end{abstract}

Keywords: Dike; Horizontal Erosion Process; Vertical Erosion Process; Overtopping Failure; Spatial Breach Test.

\section{Introduction}

One of the major issue in the hydraulic engineering is the construction and maintenance of dike embankment. The dike embankment is defined as an earthfill material (cohesive or non-cohesive materials) constructed in front of rivers and lakes to preserve the water and provide a safe environment for people lives and property $[1,2]$. The dikes embankments are classified into natural and man-made constructions [3]. Natural dikes are formed during the large movement of earth layers, due to earthquake failure, that preserves huge quantity of water volumes such as volcanic

* Corresponding author: ceashraf@usm.my

http://dx.doi.org/10.28991/cej-03091161

> This is an open access article under the CC-BY license (https://creativecommons.org/licenses/by/4.0/).

(C) Authors retain all copyrights. 
dams and landslide dams. The latter considered one of largest dams in which it may reach a hundred meters height [4]. The man-made dikes are constructed usually from homogeneous sand or gravel materials or composite structures (zones) comprised from non-cohesive and cohesive materials. The overtopping failure is occurred due to water flow above the dike crest and thus eroded the materials in the downstream and upstream slope [5]. This is due to the high water turbulence that leads to erode dike embankment and initiation of breach channel [6]. It causes series dangerous for dikes embankment all over the world. The Nina Typhoon is failed due to the continuity rainfall that increases the capacity more than $24 \%$. Overtopping failure is occurred quickly and destroy the poorly compacted soil in the dam [7].

The Teton dam failure was one of largest earthfill dikes in Idaho, USA in 1976. It is occurred as a result of seepage problem in the downstream slope, due to break in right abutment, and then developed into overtopping failure [8]. The human losses were 11 lives with damaged property of 11 billion dollars [9]. More information about different dam failures and the characteristics of erosion processes could be found in [10]. The researchers have studied different parameters that effect on the development of breach channel failure and dike slope stability such as compaction effort and the influence of boundary seepage on horizontal bed slope [11]. Series of experimental tests were conducted in small and large scale to evaluate the evolution of breach channel for dike embankment during overtopping test [12-14] for cohesive and non-cohesive dike materials [15] as well as through numerical modelling [16, 17]. One of earlier overtopping tests was conducted on fuse embankment dike with a correlation of prototype scale laws as shown in [18]. Three large flume tests have been conducted at Washington State University in 1959 to evaluate similitude laws of washout rates for erosion process during overtopping failure for the Oxbow project Idaho spillway. The main objectives of their tests results are to simulate the theory of breach erosion mechanism. Two overtopping tests have been presented to observe the mechanism of breach failure under different grain sizes at university of Auckland [19]. The first experiments include a triangle dike embankment comprised of volcanic gravel with inclinations of 1:2.5 for upstream and downstream slopes. The second series of experiments consisted from finer non-cohesive materials, ranging from the medium sand to fine gravel. A triangle pilot channel with $2 \mathrm{~cm}$ deep was cut in dike crest to initiate half breach channel for maximizing the breach widening for the flume whereas the side wall effect was neglected. For different grain sizes, the platform of breach channel, due to continuous erosion process, was similar to hourglass shape at the end of experimental tests while the slope retreat of breach channel was described to pivot about a point downstream along the base of the embankment after the erosion of downstream slope. It was observed that the shape for the breach channel is parabolic for medium sand whereas the final dimensions of breach channel failure is main dependent on falling head in the reservoir [20].

Schmocker and Hager [21] have studied the effect of scale factors on the stability of river dike embankment and breach formation by constructing thirty- nine dikes embankments at the Laboratory of Hydraulics, Hydrology and Glaciology of the Swiss Federal Institute of Technology in Zurich, Switzerland. The simple shape of dike is trapezoidal model with mild shoulder slopes and without surface protection or fine particles to control seepage flow. The experimental tests include the effect of scale series, repeatability and side-wall while the side wall effect were conducted using three flume widths of $0.1,0.2$ and $0.4 \mathrm{~cm}$. Three different scale factors of $0.25,0.5$ and 1 was used in these tests. The dike embankment was installed in flume channel without compaction with drainage element in the downstream slope to eliminate the effect of seepage flow prior to overtopping failure. They observed that the seepage flow has a direct relation with slope instability especially in grain sizes larger than $8 \mathrm{~mm}$ due to the higher soil permeability. For the effect of side wall, they were a limitation in erosion especially in the intermediate time. This is due to dominance of viscous forces over gravity forces for embankments constructed from small flume widths. Furthermore, the erosion rate is faster with high scale compared with lower one due to higher turbulence intensities, whereas the scale families of larger grain sizes induced higher sliding forces and thus clarify the breach profile in the downstream slope. To investigate the effect of flow waves on the erosion process of dike embankment, an experimental study was conducted in the Water Engineering Laboratory (LIA Lab) at the University of Cassino and Southern Lazio, Cassino (FR), Italy. The small scale of dike embankment was constructed in a horizontal rectangular channel [22].

The test includes the dam break and consequent overtopping of a downstream trapezoidal sand dike. Two initial water inflow were used for supplying the reservoir with two different uniform, non-cohesive sands for the dike embankment [23]. Both of evolution processes and velocity were measured during the tests through imaged analysis measuring techniques. The experimental tests have also been carried out for predicting the capability of a numerical code based on a morphodynamic depth-integrated two-phase approach. Although the simulation ignores the cohesion, suspended load sediment transport and seepage effects, it still able to give reasonable results for practical use. The authors have discussed the effects of inflow discharges on the development of matric suction and volumetric water content inside sand embankment dike at Universiti Sains Malaysia. The shape of coarse dike soil are trapezoidal and inserted inside small PVC flume channel to initiate overtopping failure. The spatial overtopping tests were performed by initiating a pilot channel along the side wall of flume channel. Two inflow constants of 30 and 40 1/min were supplied the flume channel to simulate the reservoir water level in front of upstream slope. Up to twelve tensiometer and Time Domain Reflectometer (TDR) were used to measure the matric suction and volumetric water content, respectively at six positions, as groups, along the upstream and downstream. The higher inflow discharges resulted in increasing the 
percentage of water content inside particles faster than the lower one for all groups. This is due to the increase of water velocity in which the higher infiltration water destroyed the meniscus pond between soil particles. The groups in the upstream slope are saturated faster than those near dike crest and downstream slope.

The erodibility process for groups in the downstream slope is faster due to the increasing of water velocity in breach channel failure whereas the last stage of erosion process is ended at the toe of upstream slope [24]. In addition, the authors have analyzed the development of water content inside coarse sand dike under two dike's slope of $1 \mathrm{~V}: 3 \mathrm{H}$ and $1 \mathrm{~V}: 2.5 \mathrm{H}$ for upstream and downstream slopes under constant inflow discharge of 301/min [25]. Sand embankment was constructed inside flume channel with pilot channel initiated along the dike crest to initiate spatial breach test. Total of twelve tensiometer and TDR sensors were distributed into six groups along the downstream and upstream slopes whereas each tensiometer and one TDR are installed in one group. The vertical distance between each tensiometer and TDR was $1 \mathrm{~cm}$ to guarantee the effect of saturation water level on occupying soil particles during overtopping failure. The gentle slope of $1 \mathrm{~V}: 3 \mathrm{H}$ resulted in increasing the infiltration of water level faster than the steep slope prior to overtopping failure while the decreasing of negative pore water pressures is higher for the latter slope after the overtopping failure. This is due to the increasing the rate of erosion process in the upstream slope of dike embankment. In this study, two spatial overtopping tests are constructed in a small flume in Hydraulic Geotechnical laboratories at the Universiti Sains of Malaysia for coarse sand and very silty sand soils. The purposes of these tests are to determine the distribution of vertical and horizontal water levels inside homogeneous dike as well as the horizontal and vertical erosion processes during overtopping tests. This is necessary due to the needs for understand the mechanism of erosion processes for practical uses in engineering fields.

\section{Materials and Methods}

Total of two spatial overtopping tests was constructed in Hydraulic Geotechnical laboratories at the Universiti Sains of Malaysia to determine the evolution of both vertical and horizontal erosion processes during overtopping failure as well as the distribution of water levels inside dike. The flume channel is constructed from PVC materials with dimensions of dimensions of 450,50, and $60 \mathrm{~cm}$ for length, width, and height, respectively. One digital camera is installed in front of flume channel to observe the vertical erosion process as well as the vertical and horizontal water distributions while the second one installed in front of the downstream slope to observe the horizontal erosion process inside dike embankment as shown in Figure 1. The video images, captured through digital cameras, are analyzed using GETDATA software while the figures are drawn using Origin 8 software. A maximum water pump of $(\mathrm{Q}=701 / \mathrm{min})$ is used to supply water inside flume channel with constant inflow discharge. Inflow discharges of 30L/min are used during the tests. A sediment box was installed at the end of flume channel to collect the eroded materials along the bed of flume channel. The dike embankments were homogeneous with dimensions of 190 and $160 \mathrm{~cm}$ length for coarse sand and very silty sand soils, respectively, $50 \mathrm{~cm}$ width, and $30 \mathrm{~cm}$ crest height. The sandy soil is classified as coarse sand (SP) while the other soil is classified as very silty sand (SML). Both of two the soil are oven-dry in $105^{\circ} \mathrm{C}$ for 24 hours to construct the dike embankment in dry condition inside flume channel. The dike was compacted every $10 \mathrm{~cm}$ until the height of $30 \mathrm{~cm}$ in the dike crest in order to conduct the dry density of $1.8 \mathrm{~g} / \mathrm{cm}$ for an accuracy comparisons A pilot channel of $10 \mathrm{~cm}$ length, $4 \mathrm{~cm}$ width, and $3 \mathrm{~cm}$ depth was cut at dike crest along the side wall of PVC channel to initiate breach channel as shown in Figure 2.

A pilot channel was cut in the dike crest in order to initiate breach channel failure before the beginning of overtopping tests with dimensions of $3 \mathrm{~cm}$ depth and $4 \mathrm{~cm}$ wide. The construction of pilot channel was carried out along the side wall of PVC whereas the wall represents the center of initial breach channel. This is important for pure observations the evolutions of water levels and erosion processes. All other parameters are not changed during overtopping tests with identical upstream and downstream slopes of $1 \mathrm{~V}: 3 \mathrm{H}$ for both soils. A constant inflow discharge of $\mathrm{Q}=30 \mathrm{~L} / \mathrm{min}$ is used to supply a reservoir water level in front of the upstream slope through using Flowmeter. The two digital cameras are used to record the water levels and erosion processes during the transition of water level from upstream into downstream slope through pilot channel. Tables 1 and 2 show the basic soil properties for coarse sand and very silty sand soil, respectively. In this study, the terms E4 and E6 refer to the experimental tests for coarse sand and very silty sand soils, respectively. The measurements of horizontal and vertical water levels, in seconds, are started from the toe of the upstream slope and ends at the beginning of dike crest while the measurements of erosion processes, in $\mathrm{cm}$, in vertical and horizontal directions began from the water flow cross the pilot channel and ends when the erosion processes in the upstream slope are finished or the materials eroded stabilized. 


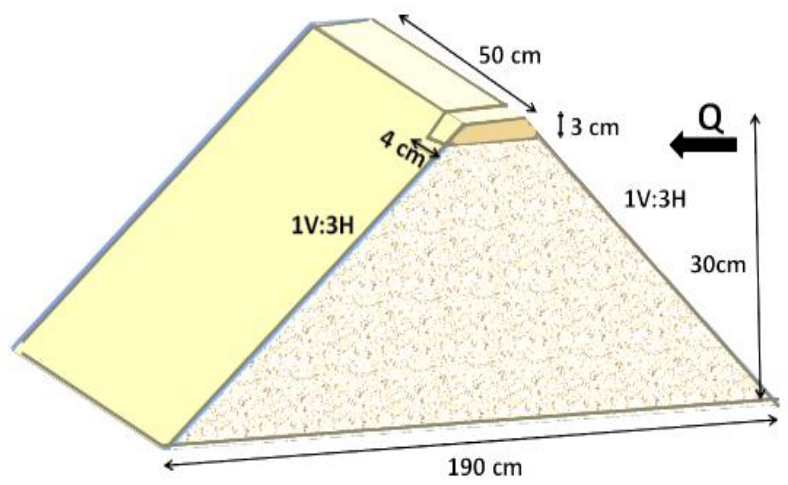

Figure 1. Geometry of dike construction with pilot channel location (shaded area)

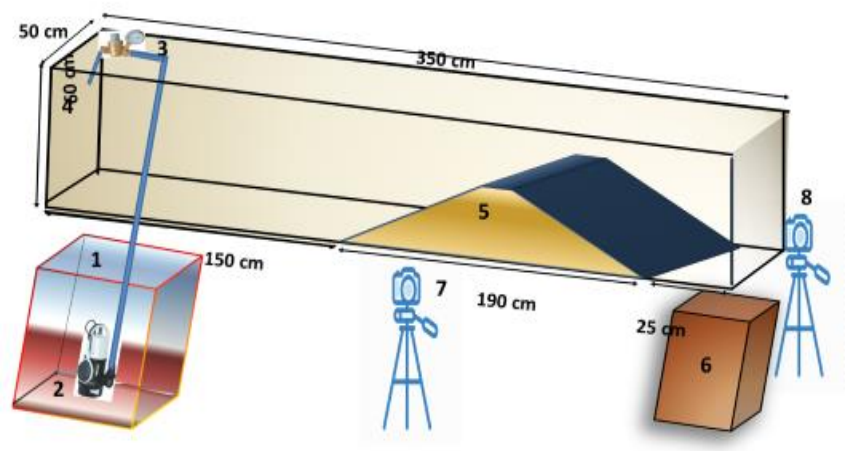

Figure 2. Component parts of flume channel: 1) Water tank, 2) Discharge pump, 3) Flowmeter, 4) Flume channel, 5) Dike construction, 6) Sediment tank, 7, 8) Camera

Table 1. Basic soil properties for coarse sand

\begin{tabular}{ccc}
\hline \multicolumn{2}{c}{ Dike components $(\%)$} & Soil Classification \\
\hline Sand & 80.59 & \\
Gravel & 19.10 & \\
Silt & 0.31 & SP \\
Clay & 0 & \\
\hline
\end{tabular}

Table 2. Basic soil properties for very silty sand soil

\begin{tabular}{ccc}
\hline \multicolumn{2}{c}{ Dike components $(\%)$} & Soil Classification \\
\hline Sand & 69.16 & \\
Gravel & 14.35 & SML \\
Silt & 16.22 & \\
Clay & 0.27 & \\
\hline
\end{tabular}

\section{Results and Discussion}

Figures 3 and 4 show the infiltration of water level inside dike for E4 and E6, respectively under constant inflow of $\mathrm{Q}=301 / \mathrm{min}$. The $\mathrm{Y}$-axis represents the dike height while the $\mathrm{X}$-axis represents the horizontal distance of dike length. One digital camera in front of the upstream slope is used to record the distribution of vertical and horizontal water levels in seconds. For both two soils, the level of infiltration water is increased gradually from the toe of upstream slope until the dike crest. It decreased the matric suction and increased volumetric water content inside particles and thus increases the easiest infiltration process. The vertical soil water pressure helps to migrate water levels from lower tension area into higher tension area in which the connection bonds, between air pressure and water pressure, within particles, are broken and gradually increases the permeability of water flow for the two soils. The rate of infiltration water is depended mainly on soils in which the presence of fine particles effects on the saturation process inside soil particles. The fine particles in E6 tend to reduce the velocity of water level higher than that in E4 in which the water saturation process is occurred faster in the toe, middle and near the crest of upstream slope for sandy soil. The water levels reached the middle of upstream slope at $\mathrm{t}=200$ and 350 seconds and at $\mathrm{t}=420$ and 630 seconds in dike crest for E4 and E6, respectively. 
Majority of upstream slope's area is saturated during the transient of water level for both soils. The measurement of water levels is ended near dike crest while the initiation of breach channel failure starts to occur inside the pilot channel.

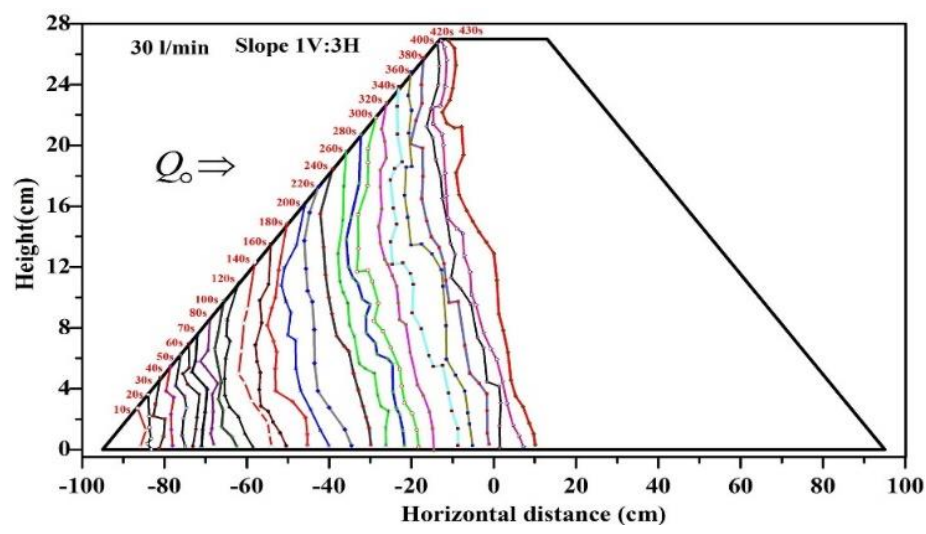

Figure 3. Water flow infiltration inside dike for $\mathbf{E} 4$

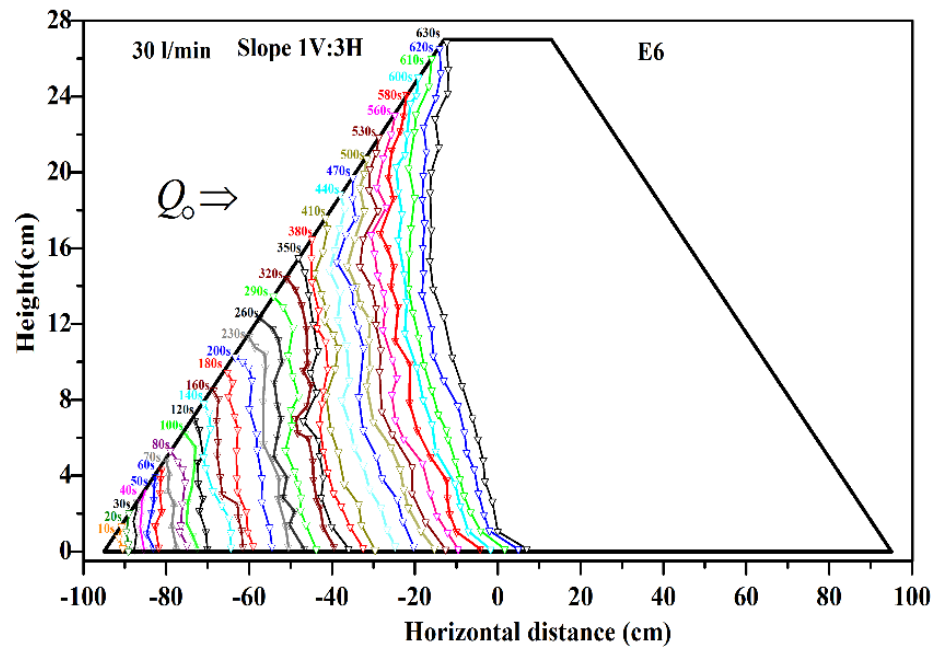

Figure 4. Water flow infiltration inside dike for E6

Figures 5 and 6 show the distribution of vertical and horizontal water inside dike embankment for E4 and E6, respectively. The values of vertical water levels are measured from the toe till the crest of the upstream slope while the horizontal water levels is measured along the horizontal distances of dike length. The differences between values of horizontal and vertical water levels at the beginning of infiltration process is convergent for both soils. For both soils, the horizontal water levels is penetrated faster inside particles compared with vertical one. This is due to the effects of soil gravity that reduce the rise of vertical water level in which the infiltration water saturated the soil particles in the horizontal distance of dike length before the elevation of water level into dike crest. The influence of gravity forces is negligible in the horizontal direction and thus the velocity of water increases. Yet, the distribution velocity of vertical water levels for both soils are reduced gradually near the dike crest. For E4, the vertical water level is 26.85 at $t=7$ minutes, respectively while for $\mathrm{E} 6$, the vertical water levels is $26.8 \mathrm{~cm}$ at $\mathrm{t}=10.5$ minutes, respectively.

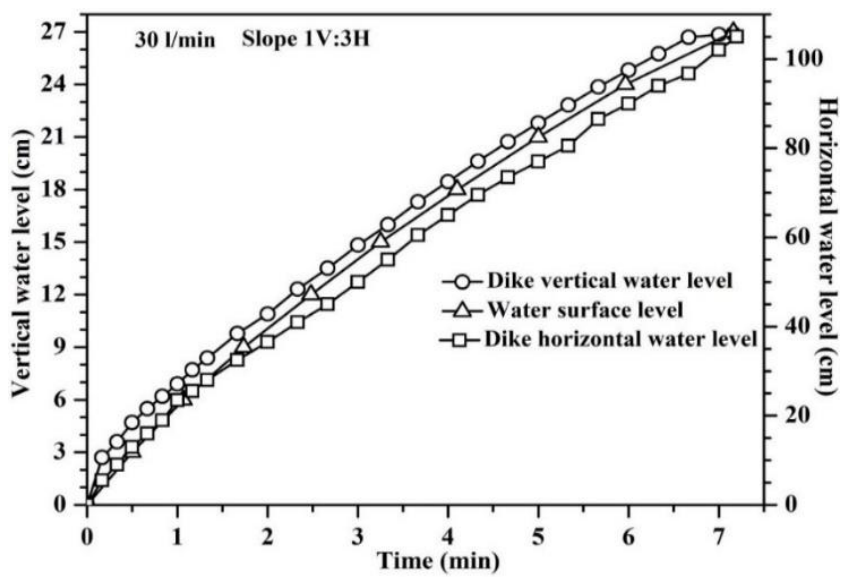

Figure 5. Distributions of vertical and horizontal water levels for $\mathbf{E} 4$ 


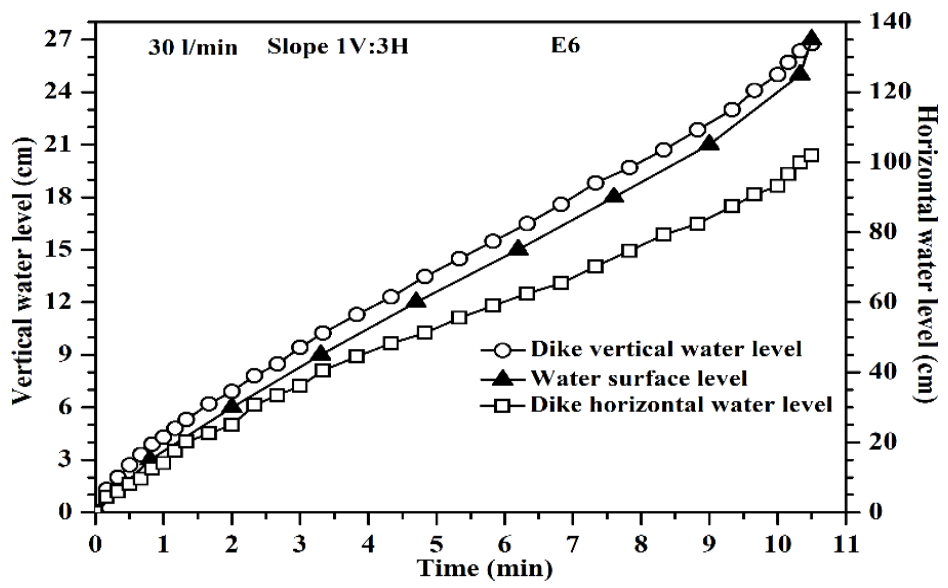

Figure 6. Distributions of vertical and horizontal water levels for E6

Figures 7 and 8 show the comparison of vertical and horizontal water levels for E4 and E6, respectively. The distribution of vertical water levels for both soils are nearly identical at $t=0.33$ minutes with levels of 3.6 and $2.01 \mathrm{~cm}$ for E4 and E6, respectively. This is due to the beginning of saturation processes near the toe of upstream slope in which the soil particles are filled with a high percentage of air flow and not yet attached to the high percentage of water content. At later minutes, the vertical water level for E4 is faster than that in E6 due to the presence of fine particles (silt and clay), in which the differences between vertical water levels are increased further at $\mathrm{t}=5.3$ minutes with levels of 22.82 and $14.39 \mathrm{~cm}$ for E4 and E6, respectively. The fine particles are absorbed a huge amount of water content due to its electronic inter-particles connections within soil particles. The permeability of E6 is lower compared with E4 and the resistance for the flow of water infiltration is higher for previous soil. Similar to the distribution of vertical water levels, the penetration of horizontal water levels is difficult in the beginning of saturation process. The velocity of horizontal water level is increased significantly at later minutes for E4. The water-filled pores has blocked the path of air flow during the infiltration of water level, due to high porosity of E4, and leads to easy the penetration of water. Measurement of horizontal water levels for E6 has lasted until $\mathrm{t}=10.5$ with levels of $100 \mathrm{~cm}$. The molecule of water is strongly attached to the surface of fine particles in E6; consequently, the channels inside the particles for the transportation of water flow will become narrow.

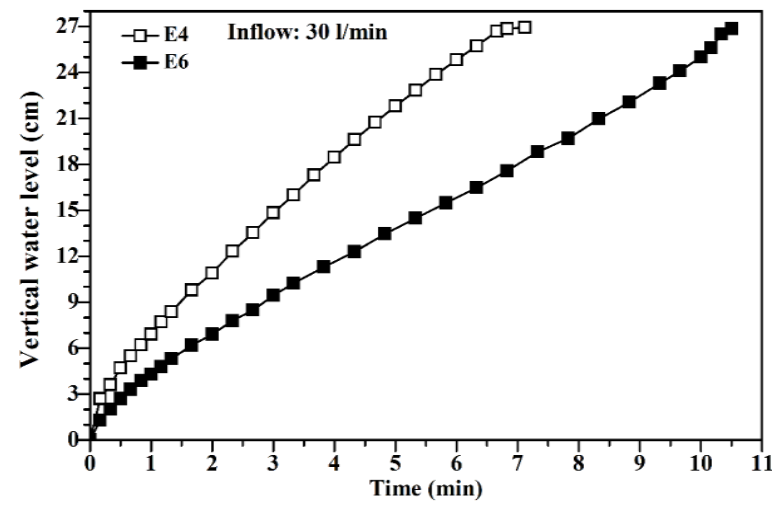

Figure 7. Comparisons between vertical water levels for E4 and E6

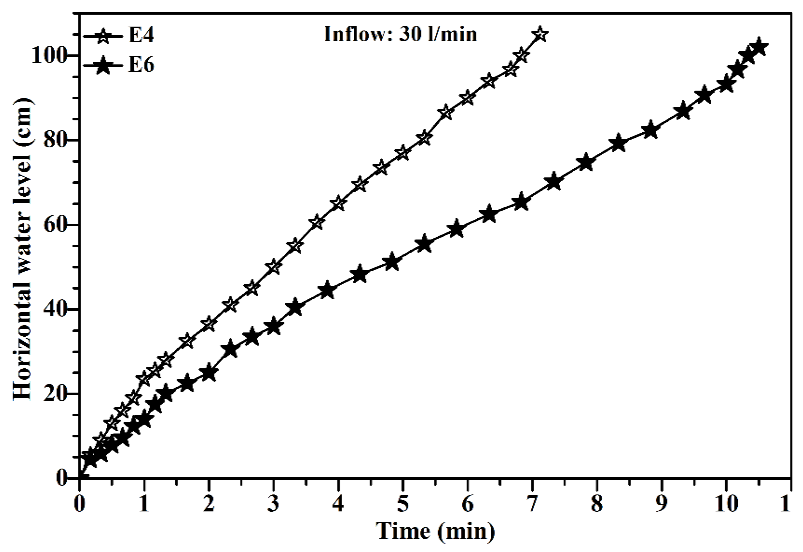

Figure 8. Comparisons between horizontal water levels for E4 and E6 
Figure 9 shows the widening of vertical erosion process in dike embankment during overtopping failure at different times in seconds from the initiation of breach channel failure at $t=$ zero seconds in dike crest until the end of erosion process at $t=190$ seconds. As mentioned previously, the observations of vertical erosion processes are occurred by one digital camera in front of dike embankment. Figures 10 and 11 show the vertical erosion process inside dike embankment for E4 and E6, respectively. The dashed line represents the paths of vertical erosion process during the development of breach channel. The vertical erosion process is initiated through crossing flow water inside pilot channel at $t=$ zero seconds. At $\mathrm{t}=10$ seconds, the vertical erosion processes for both soils is small due to high materials quantity in the dike crest, and the lack of water content percentage in the downstream slope. The development of breach channel in the downstream slope is occurred at latter minutes due to the increase of water velocity and turbulence. At $t=120$ and 180 seconds, the majority of downstream slope materials are eroded for E4 and E6, respectively in which the breach channel failure is developed in the transition area between downstream and upstream slopes and area of the upstream slope. Soils with higher fine particles are helped to stick particles together and reduce the rate of infiltration water and time of erosion materials. The enlargement of vertical breach channel is slow down gradually and then stopped, due to the reduction of erosion velocity, while most of dike crest height is disappeared at $\mathrm{t}=190$ and 390 seconds for E4 and E6, respectively.
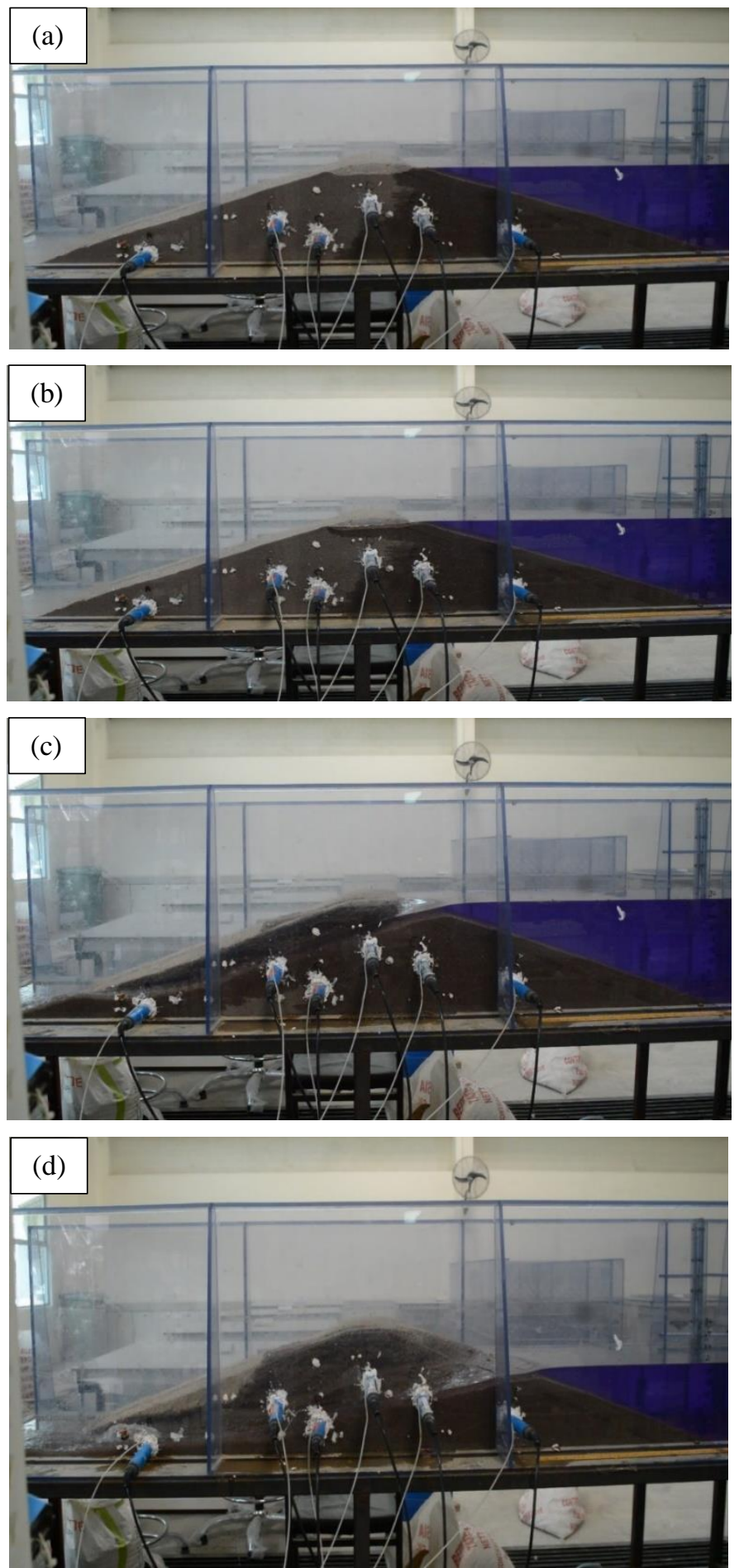

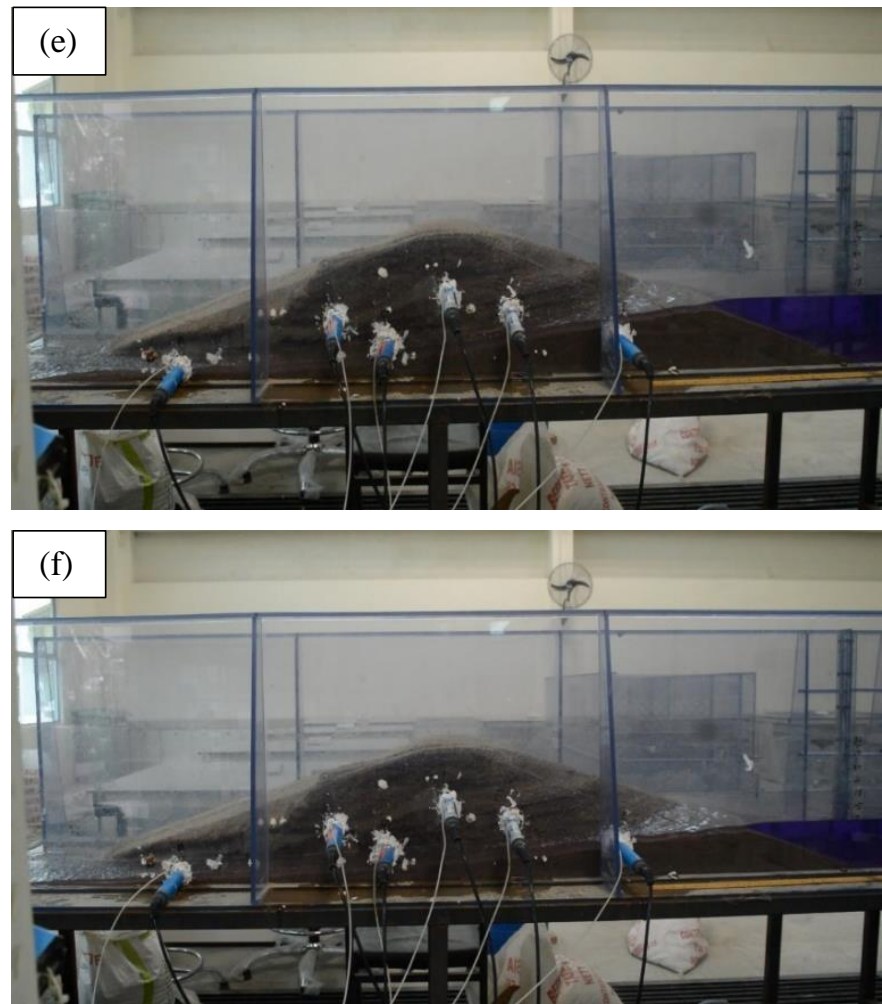

Figure 9. The development of vertical erosion process due to overtopping failure: (a) Zero seconds; (b) 10 seconds; (c) 50 seconds; (d) 100 seconds; (e) 140 seconds and (f) 190 seconds

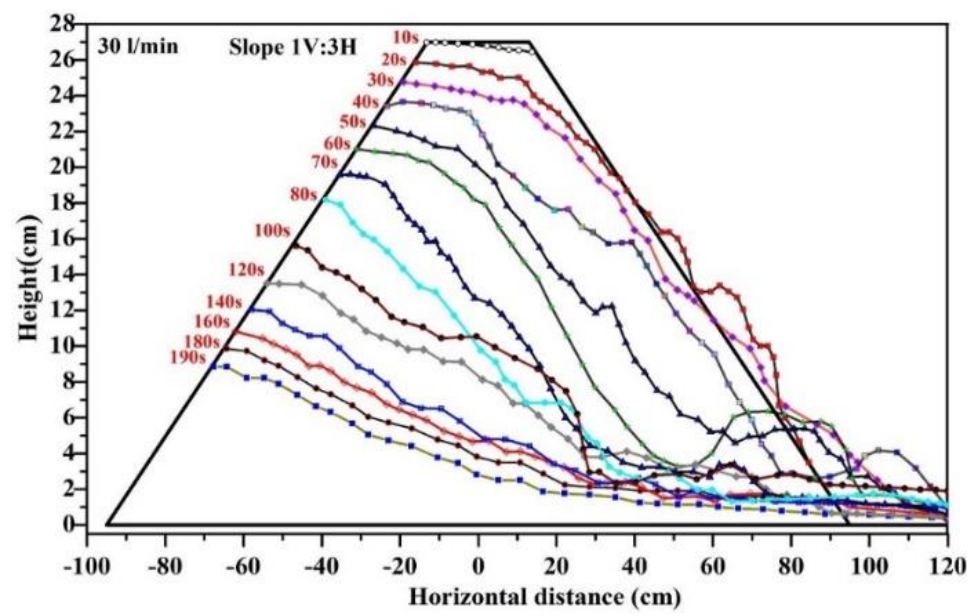

Figure 10. Dike breach profile for vertical erosion process of $\mathbf{E} 4$

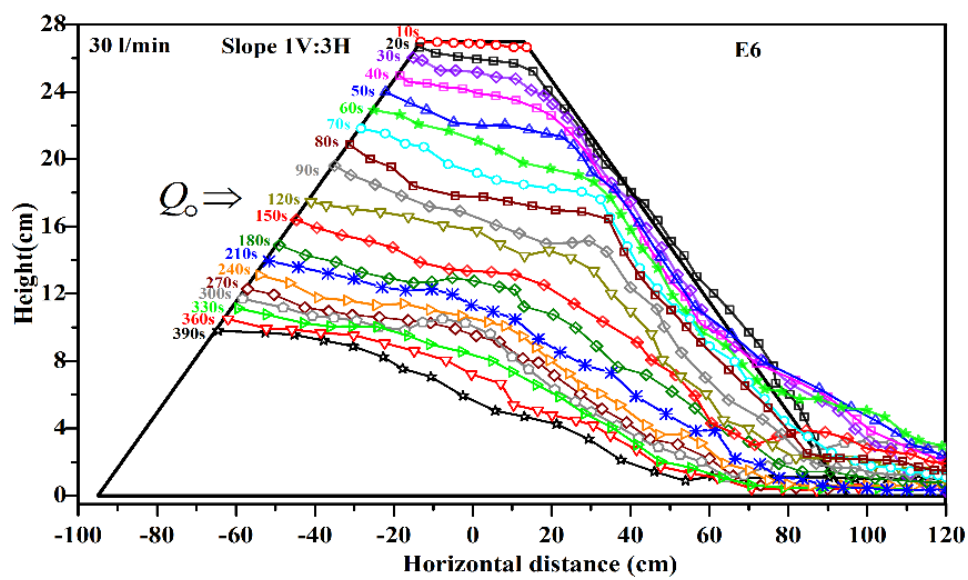

Figure 11. Dike breach profile for vertical erosion process of E6 
Figure 12 shows the comparison between the results of vertical erosion process for E4 and E6. The slight reduction of dike height is occurred at the beginning of breach failure initiation at $t=20$ seconds with dike heights of 25.85 and $26.65 \mathrm{~cm}$ for E4 and E6, respectively. This is due to the higher matric suction in soil layers below dike crest while the velocity of infiltration water is still slow to overcome the shear strength of particles. The slope failure occurred near the dike crest in E4 while it occurred near the toe of downstream slope in E6. Increasing the water velocity above the downstream slope leads to lowering dike height into 18.16 and $20.8 \mathrm{~cm}$ for E4 and E6, respectively at $\mathrm{t}=80$ seconds. Soils with a high proportion of sands increase the materials erodibility while the rate of breach channel failure is tended to decrease with a high amount of fine sands in E6. The silt and clay particles absorb water content and thus decrease the availability of water volume to initiate gully erosion. For E6, The dike slope instability resulted in steepness slope in which the breach failure mechanism is developed into headcut failures. The latter failure imposed erosive forces on the toe of the downstream slope that increases the erodibility of dike materials along the flume channel. The noticeable failure of dike slope for E4 is observed in the upper part of the downstream slope and then developed gradually into the lower part. Steepness slope has occurred similar to that occurred in E6 in which the majority of the transition area between downstream and upstream slopes and area of the upstream slope are highly eroded. The majority of the upstream slope are eroded at $\mathrm{t}=160$ and 300 seconds with dikes height of 10.81 and $11.7 \mathrm{~cm}$, respectively. The breach channel slope, for both soils, is becoming gentler during the progressive erosion process in upstream slope and gradually remained constant through the rest of breach failure in which the materials erodibility is no longer effect on dike construction. Comparisons between E4 and E6 show the differences between the rates of erosion process with particles. The very silty sand soil is more resistance against vertical erosion failure in which it lasted until $\mathrm{t}=390$ seconds.

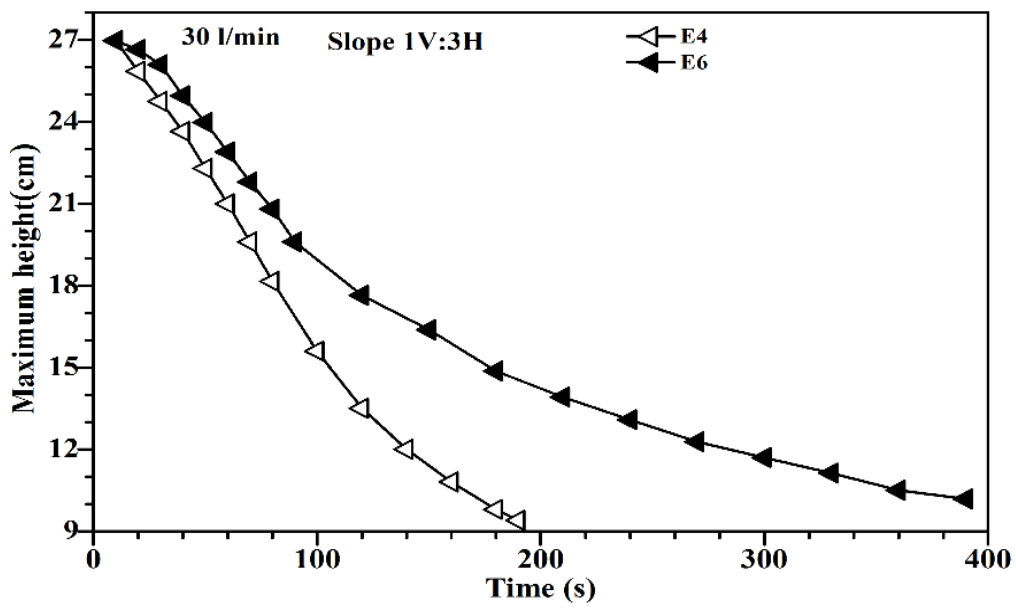

Figure 12. Comparison results of reduction dike heights inside the pilot channel

Figure 13 shows the development of horizontal erosion process due to overtopping failure that captured through camera-video system installed in front of downstream slope. Similar to vertical erosion process, the measurements for the horizontal erosion started from the flow cross the dike crest and ends until the erodibility process of dike materials is stabilized. Figures 14 and 15 show the horizontal erosion process for E4 and E6, respectively. The reduction of dike width is plotted against the horizontal distance of dike construction. The velocity of horizontal erosion is less compared with vertical erosion in the beginning of water cross above pilot channel until the toe of the downstream slope. For both soils, the beginning of noticeable reductions of dikes widths have occurred when the vertical erosion process started to erode the lower part of the downstream slope. This is due to the quick saturation of dike soil below dike crest that accelerates the vertical erosion process. The shear stress of flow water is increased in vertical erosion compared with horizontal erosion and increased the erodibility rate. The reduction of dikes width is small at $t=10$ and 20 seconds for E4 and E6 due to higher suction with soil particles. The breach channel failure is started to develop laterally at $\mathrm{t}=30$ and 40 seconds for E4 and E6, respectively in which the top and toe sections are rapidly eroded compared with the middle of dike embankment. Nevertheless, the proportion of width reduction is higher in $\mathrm{E} 4$ compared with E6 because of higher water content absorption with particles in the latter. The vertical slope of breach channel is saturated in the horizontal direction and thus overcome the tensile stress of soil particles; consequently, large slope material is eroded along the bed of flume channel at $\mathrm{t}=50$ and 70 seconds for E4 and E6, respectively. The enlargement of breach channel is continued till the upstream slope due to the continuous saturation of vertical slopes on downstream, upstream slopes as well as the transition area between the downstream and upstream slopes at $\mathrm{t}=70$ and 120 seconds for $\mathrm{E} 4$ and E6, respectively. Most of the dikes widths are eroded at $\mathrm{t}=190$ and 390 seconds, for E4 and E6, respectively in which the horizontal and vertical erosion processes are no longer effect on dike stability. 

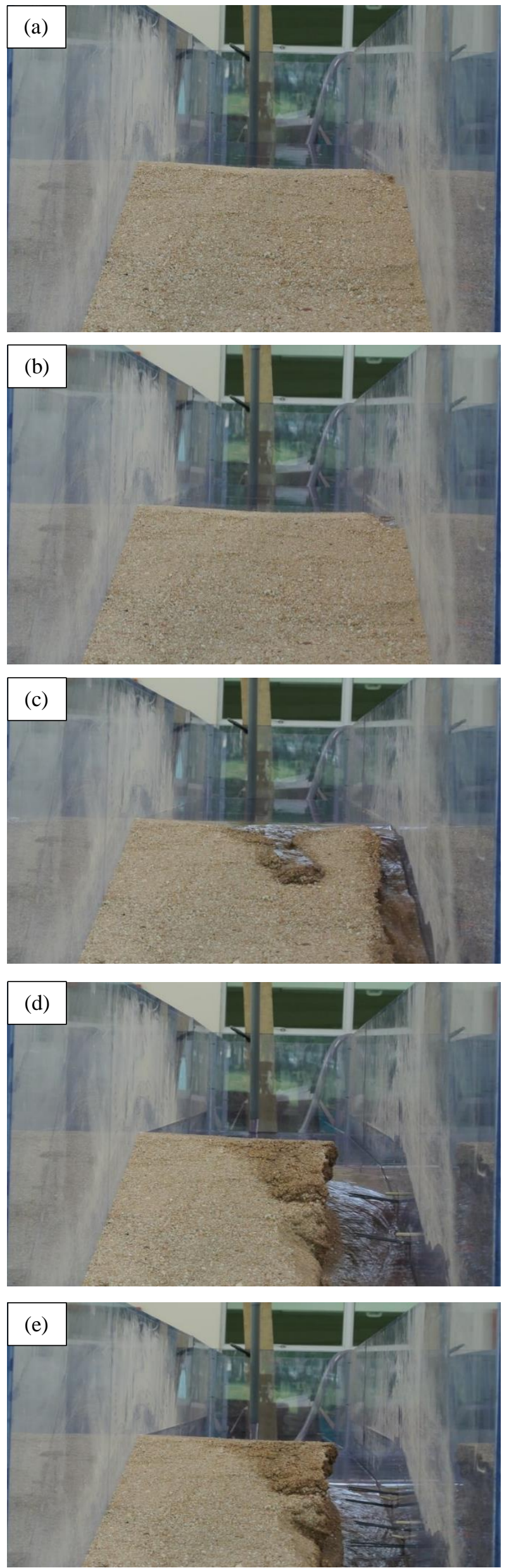


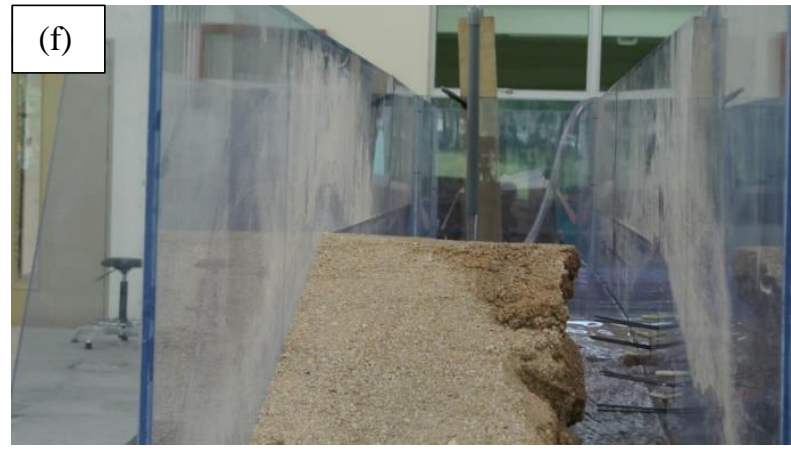

Figure 13. The development of horizontal erosion process due to overtopping failure: (a) Zero seconds; (b) 20 seconds; (c) 50 seconds; (d) 100 seconds; (e) 150 seconds and (f) 190 seconds

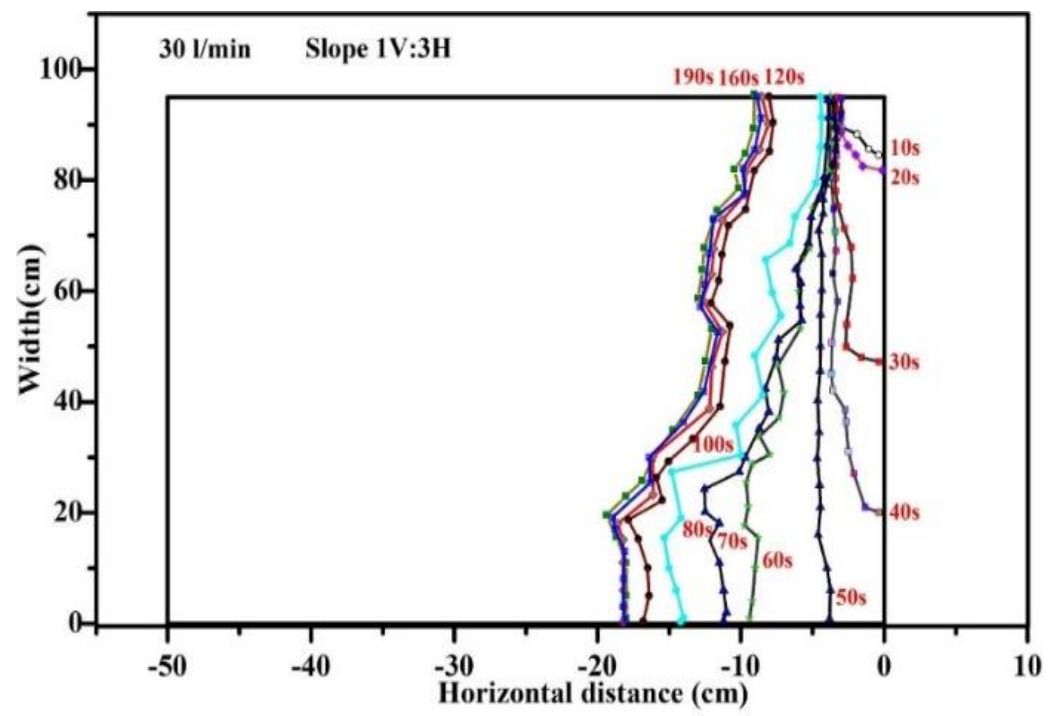

Figure 14. Reduction of dike width due to lateral erosion process for E4

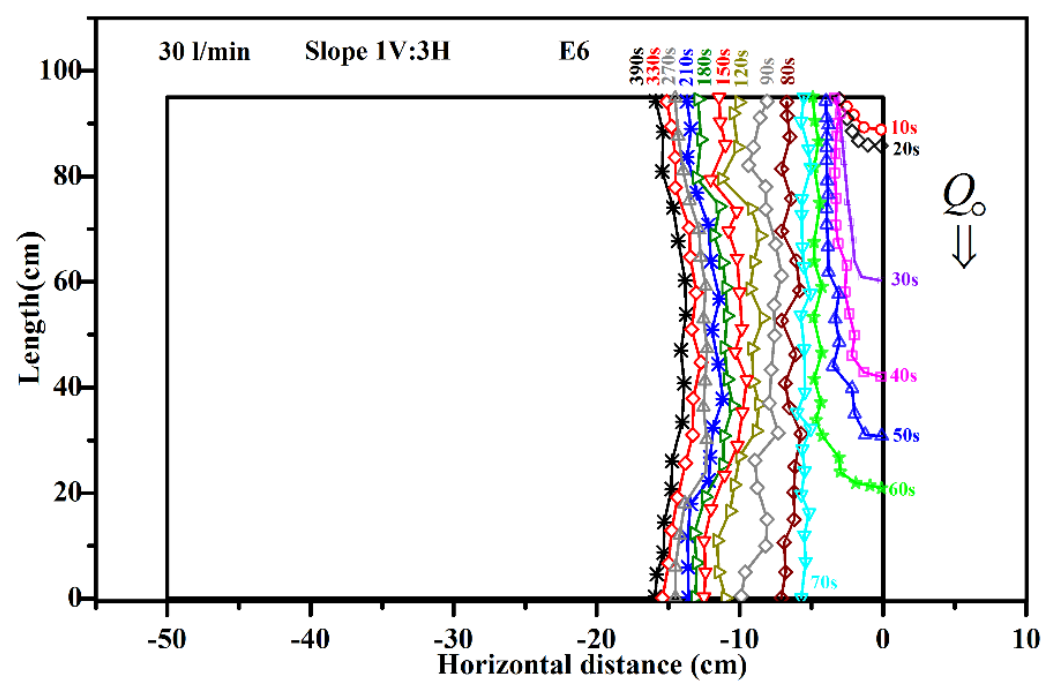

Figure 15. Reduction of dike width due to lateral erosion process for E6

Figure 16 shows the comparison reduction of dikes widths between E4 and E6. The reductions of dikes widths is small in the beginning of flow crossover the pilot channel. The convergent results for E4 and E6 are continued until $\mathrm{t}=$ 50 and 60 seconds in which the major of dike materials erodibility is due to the vertical erosion process. The inner dike slope is largely steepness due to effects of continuous enlargement of breach channel in the downstream slope for E4 and E6. Horizontal erosion process in E6 is occurred due to the breach flow shear erosion along the top surface of dike slope. The erosion failure resulted in lowering dike heights and expanded the breach development in the horizontal direction. The dike width reduction in E6 is slower than that in E4 due to the presence of fine particles proportion. The development of breach channel failure is transferred into the outer upstream slope in which approximately half of the 
dike widths are eroded along the flume channel. For E6, the erodibility rate is increased further in the lateral direction due to the discrete side-slope instability that occurs due to the increasing the velocity of falling flow near the middle of transition area of downstream and upstream slopes. For E4, the undermining of saturated dike slope is faster than that in E6 due to the high water turbulence in the porosity sand materials. At $t=160$ and 330 seconds, the dike widths are 18.9 and 14.7 seconds for E4 and E6, respectively. The cohesive particles reduce the rate of horizontal erosion process until $t=390$ seconds compared with $t=190$ seconds for $E 4$ in which the effectiveness of lateral erosion process is stabilized with dikes widths of and 15.3 and $19.38 \mathrm{~cm}$, respectively. Although the physical laboratory tests were conducted in specific configurations due to laboratory possibilities, for example on small - scale homogeneous dike embankment and specified flume width of $50 \mathrm{~cm}$, results can help for understanding the real water level distributions and erosion processes and may be useful in scientific research, for the simulation the widening of breach channel in numerical model, for conduction different scenarios on real large scale and for suggestion design and reinforcement solutions for risk prevention.

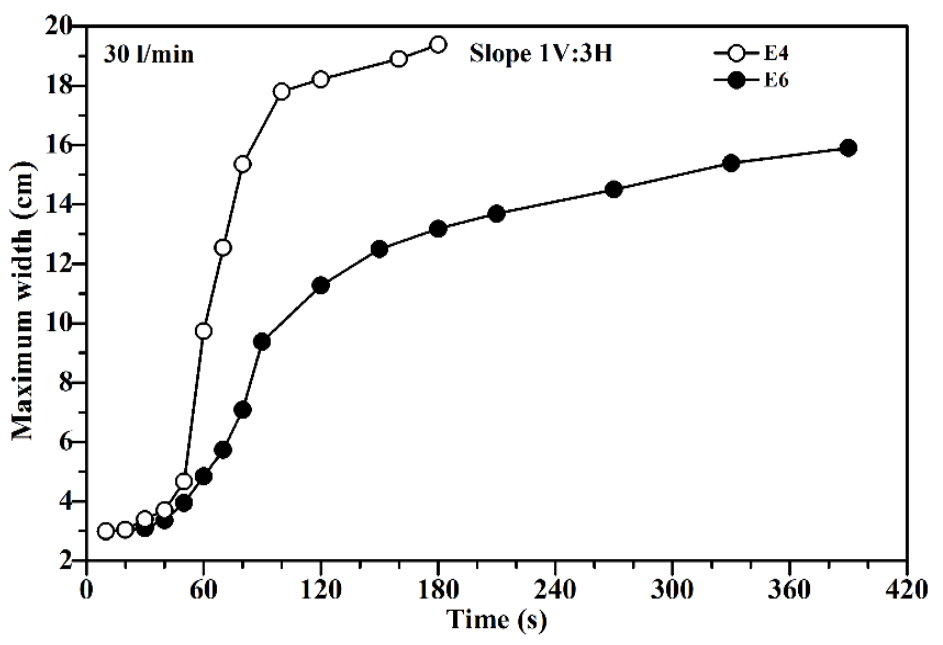

Figure 16. Comparison of widths reductions between E4 and E6

\section{Conclusion}

Up to two spatial overtopping tests were conducted to evaluate the distributions of vertical and horizontal water levels as well as the vertical and horizontal erosion processes with the assistance of two digital cameras. Two dikes embankment of sandy soil and very silty sand soil are used inside flume channel under constant inflow discharges of $30 \mathrm{~L} / \mathrm{min}$. The results indicated that the horizontal water levels is faster than the vertical one for both E4 and E6 while the horizontal and vertical water levels are faster in E4 compared with E6. The fine particles absorb a large amount of water content within particles and thus reduce the rate of infiltration water. Higher porosity of E4 leads to increase the velocity of transferring water content into other particles in downstream and upstream slopes. The vertical erosion process is occurred in the downstream slope and then transferred into dike middle and upstream slope for E4 and E6. Enlargement of breach channel is occurred slowly in E6 in the horizontal direction due to the presence of fine particles while the reduction of dike width is ended early in E4 in which most of the dike materials are eroded long the flume bed.

\section{References}

[1] Jansen. "Advanced dam engineering for design, construction, and rehabilitation, First Edition" (December 31, 1988). doi: https://doi.org/10.1007/978-1-4613-0857-7.

[2] Marwan Adil Hassan, Mohd Ashraf Mohd Ismail." Literature Review for the Development of Dike's Breach Channel Mechanism Caused By Erosion Processes during Overtopping Failure". Engineering Heritage Journal / Galeri Warisan Kejuruteraan 1(November 2017):23-30. doi: 10.26480/gwk.02.2017.23.30.

[3] John Clague, Stephen Evans. "A Review of catastrophic drainage of moraine dammed lakes in British Columbia." Quaternary Science Reviews". 19 (December 2000): 1763-1783. doi: 10.1016/S0277-3791(00)00090-1.

[4] Oliver Korup. "Recent research on landslide dams - A literature review with special attention to New Zealand". Progress in Physical Geography 26 (June 2002): 206-235. doi: 10.1191/0309133302pp333ra.

[5] Feliciano Cestero, Jasim Imran, Hanif Chaudhry. "Experimental Investigation of the Effects of Soil Properties on Levee Breach by Overtopping". Journal of Hydraulic Engineers 141 (April 2015). doi: 10.1061/(ASCE)HY.1943-7900.0000964.

[6] Saiyu Yuan, Lin Li, Farshad Amini,, \& Hongwu Tang. "Numerical Study of Turbulence and Erosion of an HPTRM-Strengthened Levee under Combined Storm Surge Overflow and Wave Overtopping". Journal of Coastal Research 293 (July 2014 ): $142-157$. doi: 10.2112/JCOASTRES-D-12- 00250.1 
[7] Defu Liu, Liang Pang, and Botao Xie. "Typhoon disaster in China: prediction, prevention, and mitigation". Natural Hazards 49 (June 2009):421-436. doi: 10.1007/s11069-008-9262-2.

[8] Ian Smalley. "The Teton dam: Rhyolite foundation + loess core = disaster". Geology Today 8 (January 1992):19-22. doi: 10.1111/j.1365-2451.1992.tb00347.x.

[9] Stacey Young, Lina Balluz, and Josephine Malilay."Natural and technologic hazardous material releases during and after natural disasters: A review". Science of the Total Environment 322 (May 2004): 3-20. doi: 10.1016/S0048-9697 (03)00446-7.

[10] Singh Vijay, and Quiroga Cesar." Dimensionless analytical solutions for dam-breach erosion" Journal of Hydraulic Research 26 (September 1988): 179-197. doi: 10.1080/00221688809499224.

[11] Tom Baldock. "Seepage effects on sediment transport by waves and currents". 26th International conference on Coastal Engineering, Copenhagen (1998). doi: 10.1061/9780784404119.274.

[12] Takaharu Kakinuma, Yasuyuki Shimizu. "Large-scale experiment and numerical modeling of a riverine levee breach". Journal of Hydraulic. Engineers. American Standard of Civil Engineering 140 (May 2014): 1-9.doi: 10.1061/(ASCE)HY.1943-7900.0000902.

[13] Lukas Schmocker, Pierre Frank, Willi Hager. "Overtopping dike-breach: Effect of grain size distribution". Journal of Hydraulic Research 52 (June 2014):559-564. doi : 10.1080/00221686.2013..878403.

[14] Gensheng Zhao. "Breach Growth in Cohesive Embankments due to overtopping". Delft Academic Press (May 2016): 129-136. doi: 10.4233/uuid:ee435ef7-f71c-493c-812b-68cf1e39aa33.

[15] Hongyan Wei, Minghui Yu, Dangwei Wang, Yitian L." Overtopping breaching of river levees constructed with cohesive sediments". Natural Hazards and Earth system sciences 16 (July 2016):1542-1551. doi: 10.5194/nhess-16-1541-2016.

[16] Guan, Mingfu, Nigel G. Wright, and P. Andrew Sleigh. "2D Process-Based Morphodynamic Model for Flooding by Noncohesive Dyke Breach.” Journal of Hydraulic Engineering 140, no. 7 (July 2014): 04014022. doi: 10.1061/(asce)hy.1943-7900.0000861.

[17] Wu, Zhou, Liu Zhijun, and Tang Lifang. "Computational Analysis of the Slope Stability of Flood Prevention and Bank Protection Engineering.” International Journal of Engineering and Technology 8, no. 2 (February 2016): 137-140. doi:10.7763/ijet.2016.v8.873.

[18] Edway Tinney, and Sam Hsu. "Mechanics of washout of an erodible fuse plug". Journal of the Hydraulics Division 87 (1961):129.

[19] Coleman Stephen, Andrews Darryl, and Webby Grant. "Overtopping breaching of non-cohesive homogeneous embankments" Journal of Hydraulic Engineering 128(August 2002): 829-838. doi: 10.1061/(ASCE)0733-9429(2002)128:9(829).

[20] Pickert Gerd, Weitbrecht Volker, and Bieberstein A. "Breaching of overtopped river embankments controlled by apparent cohesion" Journal of Hydraulic Research 49 (May 2011):143-156. doi: 10.1080/00221686.2011.552468.

[21] Lucas Schmocker, and Willi Hager. "Modelling dike breaching due to overtopping". Journal of Hydraulic Research 47 (September 2010): 585-597. doi: 10.3826/jhr.2009.3586.

[22] Stefania Evangelista, Cristiana Di Cristo, Angelo Leopardi, Giovanni de Marinis. "Experiments of dike erosion due to a wave impact". In Proceedings of the 8th WSEAS International Conference on Environmental and Geological Science and Engineering, Italy (June 2015).

[23] Stefania Evangelista, Cristiana Di Cristo, Angelo Leopardi, Giovanni de Marinis." Dam-break dry granular flows: Experimental and numerical analysis". WSEAS Transaction on Environmental and Development 10 (November 2014): 382-392.

[24] Marwan A. Hassan, and Mohd A. M. Ismail. "Effect of inflow discharges on the development of matric suction and volumetric water content for dike during overtopping tests" Proceeding of American Institute of Physics conferences, Penang, (2017). doi: 10.1063/1.5005675.

[25] Marwan A. Hassan, Mohd A. M. Ismail. "Effect of Dike Slope on the Development of Matric Suction and Volumetric Water Content during Overtopping Tests". International Journal of Civil Engineering and Technology 9 (January 2018): 253-262. 